\title{
THE EFFECT OF CORPORATE GOVERNANCE AND FINANCIAL PERFORMANCE ON DIVIDEND POLICY
}

\author{
Rochmah Yuniati ${ }^{\star 1}$, Anita Wijayanti ${ }^{2}$, Riana Rachmawati Dewi ${ }^{3}$ \\ Batik Islamic University, Indonesia \\ ryuniati1415@gmail.com *1, itax solo@yahoo.com ${ }^{2}$, riana rd40@yahoo.co.id ${ }^{3}$
}

\begin{abstract}
This study aims to examine and analyze the effect of corporate governance and financial performance on dividend policies. The dependent variable is dividend policy and the independent variable is the size of the board of commissioners, independent board of commissioners, managerial ownership, liquidity and profitability. The population of this research is 14 Manufacturing companies listed on the Indonesia Stock Exchange in the period $2015-2018$. With a total sample size of 56 and this sampling technique uses a purposive sampling method. Testing the hypothesis of this study using multiple linear regression test. The results of this study indicate that the size of the board of commissioners, the board of independent commissioners and profitability affect the dividend policy, managerial ownership and liquidity do not affect the dividend policy.
\end{abstract}

Keywords: Corporate Governance, Financial Performance, Dividend Policy

\section{INTRODUCTION}

Investors' decision to invest their capital in accompany is affected by the company's financial performance and reputation in the community. The general goal of investors to invest is to find income or return on investment. One of the desired income is dividend income. In line with the goals of a company that is maximizing profits, along with the development of financial science the company's goals must be able to create value for their owners. This is done through the distribution of dividends (Aaji and Majidah, 2018). Dividends are the company's net income distributed to shareholders in proportion to the distribution in accordance with the share owned, the distribution is based on the company's ability to generate profits and the respective company policies.

One point of view in assessing company welfare is a stable dividend payment policy. The stability of dividend distribution is very influential on investor confidence in the company. However, the phenomenon of dividend distribution in manufacturing companies is not optimal, because there are still many companies that have not been able to distribute of several factors, one of which is the declining profit level of the company.

In this study, the amount of dividend payments can be seen from two sides, namely non-financial and financial. The non-financial side is reflected in the aspects of corporate governance. The application of GCG principles can be a means of company stability and conflict alignment of the parties concerned in managing the company, both managers and management of the company. Various researchers conducted research on the relationship between dividend policy and corporate governance. Implementation of corporate governance is proxied by the size of the board, independent commissioners, managerial ownership, institutional ownership and others. Dividend policy seen from the side of Finance is implemented with financial performance ratios, including liquidity and profitability ratios.

The study will examine the effect of corporate governance mechanisms and corporate financial performance on dividend payment policies on manufacturing companies listed on the 
Indonesia Stock Exchange in the 2015 2018 period. Based on the above background, the purpose of this study is to examine the effect of corporate governance and financial performance on dividend policy. agency theory, relationships or communication between one or more people involving an agent who has a role in the delegation of business decision making authority. Agency conflict is common, where shareholder expect profits to be distributed in the form of dividends while the interests of managers want retained earnings for company growth in the future. Dividend is a payment to the owner of the company from the company's profits in the form of shares or cash. Dividend distribution proportionally according to the number of shares owned by each shareholder. There are several types of dividends, namely: Cash dividends, Dividends on assets other than cash, Debt dividends, Liquidation dividends, Stock dividends According to Gumanti (2013: 19) the dividend payment process consists of (1) Date of announcement (2) Exdividend Day (3) Date of registration of shareholders (4) Date of payment.

Dividend policy is a decision regarding the amount of dividend to be distributed to shareholders, either as cash dividends or as retained earnings (Hery,2013). Dividend policy measurement uses dividend yield (dividend yield) which relates the amount of dividend to the company's stock price and dividend [ayout ratio that links dividend per share to net income per share. corporate governance tools in the form of structures and mechanisms that provide rules and regulations in carrying out their activities to achieve organizational goals (Lukviarman, 2016:43). The principles of Corporate Governance according to the National Committee on Governance Policy, namely Transparency, Accountability. Responsibility, Independence and Equality / Fairness.
Independent commissioners are parties who have no affiliation with members of the board of commissioners and directors or major shareholders of the company. Independent commissioners of at least $30 \%$ of the total members of the Board of Commissioners. Managerial ownership is the proportion of shareholders from management involved in decision making, which includes shareholders who are either directors or commissioners in the company. Increased managerial ownership by management can recude agency costs, in addition managerial ownership can align management interests with shareholders. Financial performance is a picture of the financial condition in a company in a certain period abaout various aspects such as the collection and distribution of funds based on indicators of capital adequacy, liquidity and profitability (Jumingan, 2006:239). Financial performance is an achievement that has been achieved by company management in carrying out management of certain period assets. Liquidity is a ratio used to measure how liquid a company is by comparing components on the balance sheet, namely: total current assest with total current liabilities (Kasmir, 2012: 130). In this study, Liquidity is proxied by the Current ratio. Current Ratio ia a ratio that compares current assets with short-term debt. Profitability is the company's ability to generate profits in a certain period (Munawir, 2010: 33). Profitability ratios are ratios measuring the ability of a company to get profits from each of its operational activities. Profitability is the net result of a series of olicies and decisions in the company. Every company that is founded, is oriented so that earnings income does not sacrifice the interests of consumers to get satisfaction (Silfiana and Rachmawati, 2016). research hypothesis can be formulated as follows: The size of the board of commissioners influences dividend policy. The independent board 
of commissioners influences the dividend policy. Managerial ownership affects the dividend policy. Liquidity

\section{Types of Research}

\section{METHODS}

This type of research used in this research is quantitative research. Which emphasizes the testing of theories of measuring variables with numbers and testing analysis with statistical procedures (Ghozali, 2018).

\section{Research and Measurement Variables \\ Dependent Variable}

The dependent variable in this study is dividend policy. In this study, dividend policy is measured using a dividend payout ratio. According to Setiyowati and Sari (2017), Dividend Payout Ratio is measured using the formula:

\section{Independent Board of}

\section{Commissioners}

Independent commissioners are married parties who have affliated relations with members of the Board of

$$
D K I=\frac{\begin{array}{c}
\text { Independent Board of } \\
\text { Commissioners }
\end{array}}{\text { The Number of The }} \quad \begin{gathered}
\text { Board of } \\
\text { Commissioners }
\end{gathered}
$$

\section{Managerial Ownership}

Managerial ownership is the ownership of shareholders from management who actively participates

in corporate decision making (directors and commissioners). Measurement of managerial ownership variable with the formula, namely:

$$
K M=\begin{array}{cc}
\begin{array}{c}
\text { Number of Shares of Directors and } \\
\text { Commissioners }
\end{array} & x \\
\text { Number of Shares Outstanding } & 100 \%
\end{array}
$$

affects dividend policy. Profitability affects dividend policy.

\section{Independent Variable}

The independent variable is the variable that affects the dependent variable, the independent variables in this study are:

\section{Board of Commissioners' Size}

The size of the board commissioners is presented with the number of the board of commissioners in the company. The size of the board of commissioners is calculated by the sum of the total members of the board of commissioners. Measurement of the size of the board of commissioners using the formula, namely:

UDK $=\sum$ Board of Commissioners of The
Company

Commissioners and other revised members or with major shareholders of the company. Measurement of the Independent Board of Commissioners with the formula, namely:

Current Ratio $(C R)=\frac{\text { Current Asset }}{\text { Current Liability }}$

\section{Liquidity}

Current Ratio is a ratio to measure the ability of companies to pay shortterm liabilities or debt that are due immediately when billed as a whole. In other words, how much current assets are available to cover short-term liabilities that are immediately due. Liquidity ratio measurement with the formula, namely: 


\section{Profitability}

Profitability is the ability of efficient management of assets in a certain period to generate profits. Proxy profitability with Return of Assets (ROA). Measurement of this ratio using the following formula: :

$$
R O A=\frac{\text { Net Profit after tax }}{\text { Total Assets }} \times 100 \%
$$

\section{Data Source}

The data source used in this study is the brother data. Secondary data is data obtained indirectly through intermediary medi, usually in the form of evidence, notes or documentary data either published or unpublished (Indriantoro \& Supomo, 1999). Secondary data in this study were obtained by researchers from annual reports and financial reports from manufacturing sector companies listed on the Indonesia Stock Exchange period 2015-2018 (www.idx.co.id)

\section{Population And Sampling}

The population in this study were all manufacturing sectors with 144 companies. The sample in this study was taken by purposive sampling method. The sample selection criteria in this study are:

Tabel 1. Sample Criteria

\begin{tabular}{llc}
\hline No & \multicolumn{1}{c}{ Information } & Jumlah \\
\hline $1 \quad \begin{array}{l}\text { Manufacturing companies listed on the Indonesia Stock } \\
\text { Exchange in 2015-2018. }\end{array}$ & 144 \\
$2 \quad \begin{array}{l}\text { Manufacturing companies that do not report successive } \\
\text { annual reports for the 2015-2018 period. }\end{array}$ & $(17)$ \\
$3 \quad \begin{array}{l}\text { Manufacturing companies that have not consistently } \\
\text { distributed cash dividends during 2015-2018. }\end{array}$ & $(63)$ \\
$\quad \begin{array}{l}\text { Manufacturing companies that did not use the rupiah during } \\
\text { 2015- 2018. }\end{array}$ & $(20)$ \\
$\quad \begin{array}{l}\text { Manufacturing companies that do not have complete data } \\
\text { for the years 2015-2018. }\end{array}$ & $(26)$ \\
$\begin{array}{l}\text { Number of Companies Sampled } \\
\text { Outlier } \\
\text { Number of Samples } \\
\text { Total Samples (4 years) }\end{array}$ & $\mathbf{1 8}$ \\
\hline
\end{tabular}

\section{Data Analysis Method}

This research was conducted by sattisrical methods with the help of the SPSS program to estimate the effect of the independent variables on the dependent variable. Then the data analysis in this study is described as follows:

\section{Descriptive Analysis}

Data processing analysis which aims to provide an overview of data seen from the average value, standard deviation, variance, maximum, minimum, sum, range, kurtosis and skewness (Ghozali, 2018). Measurements used in this study are the mean, standard deviation, minimum value, and maximum value.

\section{Classic Assumption Test}

The classic assumption test is performed to ensure that the sample under study is free from multicollinearity, autocorrelation, heteroscedasticity and normality disorders.

\section{Data Normality Test}

According to Ghozali (2018: 161), the normality test aims to test whether the regression model, confounding or residual variables have a normal distribution. The test was carried out by the Kolmogorof Smirnov test static test 
to find out whether the data was normally distributed or not. The basis for decision making from one-sample Kolmogorof Smirnov is: 1 . If probability> 0.05 shows normal distribution patterns, the regression model meets the normality assumption. 2 . If the probability $<0.05$ does not show a normal distribution pattern, then the regression model does not meet the normality assumption.

\section{Multicollinearity}

Multicollinearity test is used to test whether the regression model found a correlation between independent variables. To detect the presence or absence of multicollinearity by looking at the value of tolerance and inflation inflation facto (Ghozali, 2018). The tolerance value to measure the variability of selected independent variables that are not explained by other independent variables. So the lowest tolerance value means the highest VIF value. The cut off value used to indicate the presence of multicollinearity is a tolerance value $\leq 0.10$ or equal to a VIF value $\geq 10$ (Ghozali, 2018).

\section{Autocorrelation}

The autocorrelation test aims to test whether in the linear regression model there is a correlation between confounding errors in the $t$ period with confounding errors in the $t-1$ period (before), a good regression model is a regression that is independent of autocorrelation (Ghozali, 2018). One way to detect autocorrelation with the Durbin Watson test, the indocator is as follows: If the value of $\mathrm{dU}<\mathrm{DW}<4-\mathrm{dU}$, then no autocorrelation occurs. If the value of $d U>D W>4-d U$, then an autocorrelation occurs.

\section{Heteroscedasticity}

Heteroscedasticity test proves whether the regression model occurs in variance inequality from the residue of one observation to another. If variations and residues, one variation to another observation is still called homokedastisitas and if different is called heteroscedasticity. A good regression model is homokedasticity or heteroscedasticity does not occur (Ghozali, 2018). To test the presence or absence of heteroscedasticity in this study using the glacier test. The testing criterion is a significance level of significance above 5\%, then the regression model does not contain heteroscedasticity.

\section{Multiple Regression Analysis}

This research was tested using multiple regression models. Multiple linear regression tests the effect of independent variables on the dependent variable (Ghozali, 2018). The regression model is formulated as follows:

$$
\begin{aligned}
Y= & \alpha+\beta 1 X 1+\beta 2 X 2+\beta 3 X 3+ \\
& \beta 4 X 4+\beta 5 X 5+e
\end{aligned}
$$

Information:

$$
\begin{array}{ll}
\alpha & =\text { A Constant } \\
\text { Y } & =\text { Dividend Policy } \\
\text { X1 } & =\text { Board of Commissioners' Size } \\
\text { X2 } & =\quad \text { Independent Board of } \\
& \text { Commissioners } \\
\text { X3 } & =\text { Managerial Ownership } \\
\text { X4 } & =\text { Liquidity } \\
\text { X5 } & =\text { Profitability } \\
\beta & =\text { Regression Coefficient } \\
\text { e } & =\text { Error (Confounding Factor) }
\end{array}
$$

\section{Model Feasibility Test (F Test)}

$F$ test is performed to test simultaneously the independent variables have an influence on the dependent variable. If Fcount $>\mathrm{F}$ table or sign $<0.05$ indicates that the regression model is feasible. If Fcount $<\mathrm{F}$ table or sign $>0.05$, the model used is not feasible.

\section{Partial Hypothesis Test (T Test)}

The statistical test $t$ shows how far the effect of each variable individually in explaining the variation of the dependent variable and is used to find out whether 
there is an influence of the independent variable on the dependent variable with a significance level of 0,05 . The t test test criteria are as follows: (1) if the sign value $>0,05$ then $\mathrm{H} 0$ is accepted or $\mathrm{H} 1$ is rejected and if the $t$ value is $<t$ table, then the independent variable has no effect on the dependent variable. (2) if the sign value $<0,05$ then $\mathrm{H} 0$ is rejected or $\mathrm{H} 1$ is rejected and if the value of $\mathrm{t}$ count $>\mathrm{t}$ table then the independent variable influences the dependent variable.

\section{Coefficient of Determination $\left(\mathbf{R}^{2}\right)$}

The coefficient of determination is used to determine the percentage change in the dependent variable caused by the independent variable
(Ghozali, 2018). The coefficient of determination is zero to one, the closer to the number one, the better the model. The greater Adjusted $\mathrm{R}$ Square, the percentage change in the dependent variable caused by the independent variable will be higher.

\section{RESULT AND DISCUSSION}

Based on table 1, there are a total of 56 sample data from 18 Manufacturing Sector companies listed on the Indonesia Stock Exchange for 4 years period. After processing the data, 4 outliers were found because of extreme data. So the number of samples obtained was 14 companies. List of companies used as research samples, namely:

Table 2. List of companies that are research samples

\begin{tabular}{clc}
\hline No & \multicolumn{1}{c}{ Company Name } & Company Code \\
\hline 1 & PT. Duta Pertiwi Nusantara Tbk & DPNS \\
2 & PT. Gudang Garam Tbk & GGRM \\
3 & PT. Indal Alumunium Industry Tbk & INAI \\
4 & PT. Indofood Sukses Makmur Tbk & INDF \\
5 & PT. Kimia Farma (PERSERO) Tbk & KAEF \\
6 & PT. KMI Wire and Cable Tbk & KBLI \\
7 & PT. Kabelindo Murni Tbk & KBLM \\
8 & PT. Kalbe Farma Tbk & KLBF \\
9 & PT. Lionmesh Prima Tbk & LMSH \\
10 & PT. Supreme Cable Manufacturing \& Commerce Tbk & SCCO \\
11 & PT. Sekar Laut Tbk & SKLT \\
12 & PT. Selamat Sempurna Tbk & SMSM \\
13 & PT. Mandom Indonesia Tbk & TCID \\
14 & PT. Tempo Scan Pacific Tbk & TSPC \\
\hline
\end{tabular}

\section{Descriptive Statistics}

Descriptive statistics are used to find out the data in this study by using the mean, maximum, minimum and standard deviation of each independent variable, namely UDK, DKI, KM, CR and ROA.

Table 3. Descriptive Statistics

\begin{tabular}{llrrrc}
\hline Information & $\mathbf{N}$ & Minimum & Maximum & Mean & Std. Deviation \\
\hline UDK & 56 & 2,00000 & 8,00000 & 4,3571429 & 1,72076697 \\
DKI & 56 & 0,20000 & 0,50000 & 0,4038254 & 0,08580671 \\
KM & 56 & 0,00001 & 0,25151 & 0,0485418 & 0,06990234 \\
CR & 56 & 0,99250 & 15,1646 & 3,2002343 & 2,86820655 \\
ROA & 56 & 0,01453 & 0,26150 & 0,0803627 & 0,05721484 \\
DPR & 56 & 0,08384 & 0,74922 & 0,3289354 & 0,17957852 \\
Valid N & 56 & & & & \\
\hline
\end{tabular}




\section{Classic Assumption Test Normality Test}

The normality test aims to test in the regression model, the residual variable has a normal distribution. Testing for normality using the Kolmogorov Smirnov test.

Table 4 . Normality Test Results

\begin{tabular}{clll}
\hline Variable & Sign & Std & Conclusion \\
\hline $\begin{array}{c}\text { Asymp. Sig. } \\
\text { (2-Tailed) }\end{array}$ & 0,189 & $>0,05$ & Normal \\
\hline
\end{tabular}

Based on table 4, it can be seen the significance of 0.189 , which is greater than 0.05 , it can be concluded that the data is normally distributed.

\section{Multicollinearity}

Multicollinearity test to test whether there is a correlation between independent variables, if there is a correlation between variables, it is said that the regression model is not good. Multicollinarity can be seen from the value of tolerance and VIF.

Table 5. Multicolienarity Test Results

\begin{tabular}{lcccc}
\hline \multicolumn{1}{c}{ Variabel } & Tolerance & Std & VIF & Std \\
\hline UDK & 0,710 & $>0,1$ & 1,408 & $<10$ \\
DKI & 0,852 & $>0,1$ & 1,174 & $<10$ \\
KM & 0,657 & $>0,1$ & 1,522 & $<10$ \\
CR & 0,924 & $>0,1$ & 1,083 & $<10$ \\
ROA & 0,823 & $>0,1$ & 1,215 & $<10$ \\
\hline
\end{tabular}

Based on table 5, it can be concluded that the test results show that the analyzed data does not occur multicollinearity, because all variables have a tolerance value $>0,10$ and a VIF value $<10$.

\section{Autocorrelation Test}

Autocorrelation testing aims to test whether in the linear regression model there is a correlation between the error of the intruder in the period $t$ with the error of the intruder in the period t- 1 (previous). The testing method uses DW test.

Table 6. Autocorrelation Test Results

\begin{tabular}{ccc}
\hline Model & Durbin-Watson & Std. Durbin-Watson \\
& & \\
\hline 1 & 1,821 & Du $<$ DW $<4$-dU \\
& & $1,7678<2,2322$ \\
\hline
\end{tabular}

Based on table 6 that the DW value is between 1.7678 (dU) and 2.2322 (4-dU), it can be concluded that there was no autocorrelation in the regression model of this study.
Heteroscedasticity testing aims to test whether the variance inequality in the regression model, if heteroscedasticity occurs then the regression model can be said to be not good.

\section{Heteroscedasticity Test}


Table 7. Heteroskedicity Test Results

\begin{tabular}{ccc}
\hline Model & Sign. & Std \\
\hline UDK & 0,452 & $>0,05$ \\
DKI & 0,636 & $>0,05$ \\
KM & 0,594 & $>0,05$ \\
CR & 0,209 & $>0,05$ \\
ROA & 0,367 & $>0,05$
\end{tabular}

Based on table 7 that of each independent variable is UDK of 0.452 , DKI of $0.636, \mathrm{KM}$ of 0.594 , CR of 0.209 and $\mathrm{ROA}$ of 0.367 where all variables

\section{Multiple Linear Regression Analysis Regression Model}

indicate greater than 0.05 . It can be stated that the regression model does not occur heteroscedasticity.

Table 8. Regression Model Test Results

\begin{tabular}{cc}
\hline Model & Unstandarized Coefficients \\
& $\boldsymbol{B}$ \\
\hline (Constant) & $-0,252$ \\
UDK & 0,049 \\
DKI & 0,999 \\
KM & $-0,043$ \\
CR & 0,008 \\
ROA & $-1,006$ \\
\hline
\end{tabular}

Based on the results of the regression model test in table 8 , the regression equation is:

$$
\begin{array}{r}
Y=-0,252+0,049(\mathrm{UDK})+0,999(\mathrm{DKI})- \\
\quad 0,043(\mathrm{KM})+0,008(\mathrm{CR})-1,006 \text { (ROA) }
\end{array}
$$

The interpretation of the regression above is:

A constant value of $-0,252$, explains that the model is assumed to be equal to zero then the dividend policy will decrease by 0.252 . The coefficient value of UDK is 0,049 , explaining that each increase in UDK is 1 unit then increasing the dividend policy by 0,049 . The coefficient value of DKI is 0,999 , explaining that every 1 unit increase in
DKI increases the dividend policy by 0,999 . The KM coefficient is $-0,043$, explaining that each increase in $\mathrm{KM}$ of 1 unit will reduce the dividend policy by 0,043 . The coefficient of CR is 0,008 , explaining that each increase of 1 unit of $\mathrm{CR}$ increases the dividend policy by 0.008 . ROA coefficient value of $-1,006$, explains that an increase in ROA 1 unit will reduce the dividend policy of 1,006 .

\section{Model Feasibility Test (F Test)}

The $F$ statistical test shows that the independent variable used as a model influences the dependent variable. 
JASa (Jurnal Akuntansi, Audit dan Sistem Informasi Akuntansi)

Vol. 4 No. 3/ December 2020

ISSN 2550-0732 print / ISSN 2655-8319 online

Table 9. Model Feasibility Test Results

\begin{tabular}{ccccc}
\hline nodel & Fhitung & Ftabel & Sig. & Std. \\
\hline 1 & 7,074 & 2,40 & 0,000 & 0,05 \\
\hline
\end{tabular}

Based on table 9, the results of the $F$ test are obtained $f$ value of 7,074 more than the $f$ table of 2,40 with a significance level of $0,000<0,05$, it can be concluded that the regression model is feasible.

\section{Hypothesis Test ( $t$ test)}

T test was used to determine the effect of each independent variable on the dependent variable.

Table 10. Hypothesis Test Results

\begin{tabular}{cccccc}
\hline Variabel & t-hitung & t-tabel & Sig. & Kriteria & The Result \\
\hline UDK & 3.826 & 2.009 & 0.000 & $<0,05$ & Received \\
DKI & 4.239 & 2.009 & 0.000 & $<0,05$ & Received \\
KM & -0.117 & 2.009 & 0.862 & $<0,05$ & Rejected \\
CR & 1.234 & 2.009 & 0.255 & $<0,05$ & Rejected \\
ROA & -2.637 & 2.009 & 0.002 & $<0,05$ & Received \\
\hline
\end{tabular}

\section{Hypothesis Test 1}

Based on table 10 of the results of the Board of Commissioners' hypothesis test that $t$ count is 3,826 , thus $t$ count $>t$ table $(3,826>2,009)$ and significance $<0.05(0,000<0.05)$ which statistically the Board of Commissioners size variable influences the Dividend or $\mathrm{H} 1$ Policy variable accepted .

\section{Hypothesis Test 2}

Based on table 10 of the Independent Commissioner Hypothesis test results that $t$ count is 4.239 , thus $t$ count $>\mathrm{t}$ table $(4.239>2.009)$ and significance $<0.05(0.000<0.05)$ which statistically the Independent Board of Commissioners variable influences Dividend or $\mathrm{H} 2$ Policy variables.

\section{Hypothesis Test 3}

Based on table 10 results of the Managerial Ownership hypothesis test that $\mathrm{t}$ count is -0.117 , thus $\mathrm{t}$ count $<\mathrm{t}$ table $(-0.117<2.009)$ and significance $>$ $0.05(0.907>0.05)$ which statistically
Managerial Ownership variable does not affect Dividend Policy variables or H3 rejected.

\section{Hypothesis Test 4}

Based on table 10 Liquidity hypothesis test results that $t$ arithmetic of 1,234 , thus $t$ arithmetic $<$ table $(1,234$ $<2,009)$ which statistically the Liquidity variable does not affect the Dividend Policy variable or $\mathrm{H} 4$ is rejected.

\section{Hypothesis Test 5}

Based on table 10 the results of the hypothesis test Profitability $t$ count of -2.637 , thus $t$ count $<$ t table $(-2.637$ $<2.009)$ which statistically variable Profitability does not affect the Dividend Policy variable or $\mathrm{H} 5$ is rejected.

\section{Determination Coefficient Test (Adj $\mathbf{R}^{2}$ )}

The coefficient of determination aims to measure how far the model's independence in explaining the variation of the dependent variable. 
Table 11. Test Results Coefficient of determination

\begin{tabular}{cc}
\hline Model & Adjusted R Square \\
\hline 1 & .356 \\
\hline
\end{tabular}

Based on table 11 the coefficient of determination test results, it can be seen the Adjusted R Square value is 0.356 or $35.6 \%$. This means that $64.4 \%$ of the Dividend Policy can be explained by the variables of the Size of the Board of Commissioners, Independent Board of Commissioners, Managerial Ownership, Liquidity and Profitability. While the remaining $64.4 \%$ is explained by other variables not examined in this study.

\section{Discussion}

\section{UDK's Influence on Dividend Policy}

The results of the analysis as presented in table 10 show that UDK influences Dividend Policy. The board of commissioners can reduce the amount of agency problems between shareholders and company managers so that the company's welfare can be controlled through dividend payments. This research is in line with Elmagrhi et.al (2017) and Shahid et.al (2016) which results in UDK having an effect on Dividend Policy.

\section{Effect of DKI on Dividend Policy}

The results of the analysis as presented in table 10 show that DKI affects Dividend Policy. The supervisory function of the independent board of commissioners, will reduce the problem of agency costs in the company. So that the more independent commissioners in a company, the more dividends can be attributed to the company. This research is in line with the research of Setiyowati and Sari (2017) which resulted in DKI influencing Dividend Policy.

\section{Effect of KM on Dividend Policy}

The results of the analysis as presented in table 10 show that KM does not affect the Dividend Policy because the proportion of managerial ownership of the total number of shareholders in each manufacturing company listed on the Indonesia Stock Exchange (IDX) for the 2015-2018 period is very small, namely below $30 \%$ of the number of shareholders in the company. This research is in line with the research of Agus Suyono (2018) which shows that KM does not influence Dividend Policy.

\section{Effect of CR on Dividend Policy}

The results of the analysis as presented in table 10 show that CR has no effect on dividend policy, this is because companies with high liquidity ratios provide an illustration that the company is not effective in using working capital due to the proportion of unfavorable current assets that causes the company less efficient. The company is more focused on meeting its short-term obligations rather than dividends. This research is in line with Apriliani's study (2017) which shows that $\mathrm{CR}$ has no effect on Dividend Policy.

\section{Effect of ROA on Dividend Policy}

The results of the analysis as presented in table 10 show that ROA affects Dividend Policy. Companies with a high level of profitability tend to distribute dividends stably or tend to be large. It can be said that the company has a good performance where the return on investment is getting better, it 
can give a signal that the company is in good condition. Dividends are taken from the net profit obtained by the company from the company's operating results. This study is in line with the research of Agus Suyono (2018) that ROA affects the Dividend Policy.

\section{CONCLUSION}

This study aims to examine the effect of Corporate Governance (Board of Commissioners Size, Independent Board of Commissioners, Managerial Ownership) and Financial Performance (Liquidity and profitability) on Dividend Policy (DPR). Based on the test results, hypothesis 1 states that the size of the board of commissioners influences dividend policy. Hypothesis 2 states that the Independent Board of Commissioners influences the dividend policy. Hypothesis 3 states that Managerial Ownership influences Dividend Policy. Hypothesis 4 states that liquidity affects the Dividend Policy. Hypothesis 5 states that profitability influences the dividend policy. The results of the research conducted concluded that the variable size of the Board of Commissioners, Independent Board of Commissioners and Profitability has an influence on the Dividend Policy. Whereas Managerial Ownership and Liquidity Variables do not have an influence on Dividend Policy. From the results of the research above, it is expected to be able to increase knowledge related to corporate governance mechanisms and corporate financial performance that affect Dividend Policy. For companies, it can improve better performance so that investors are interested to invest in the company.

\section{REFERENCES}

Afriyeni, and Kartika Deas. (2019). "Pengaruh Profitabilitas, Leverage, Dan Growth Terhadap Kebijakan Dividen Pada Perusahaan Property, Real Estate, And Building Contruction Yang Terdaftar Di BEI." Jurnal Benefita 4(3): 399-411.

Agus Suyono, Nanang. (2018). "FaktorFaktor Yang Mempengaruhi Dividend Payout Ratio ( DPR ) Pada Perusahaan Perbankan Di Bursa Efek Indonesia." Journal of Economic, Management, Accounting and Technology (JEMATech) 1(1): 105-13.

Apriliani, A. (2017). "Faktor-Faktor Yang Mempengaruhi Kebijakan Dividen Pada Perusahaan Manufaktur Di Bursa Efek Indonesia." JURNAL BISNIS DAN AKUNTANSI ISSN: 1410 - 9875 19(1).

Ayu, Ida, Putri Pertami, Ida Bagus, and Panji Sedana. (2018). "Faktor -

Faktor Yang Mempengaruhi Kebijakan Dividen Pada Perusahaan Manufktur Di Bursa Efek Indonesia." E-Jurnal Manajemen Unud 7(7): 3623-52.

Banani, Ade, and Eri Apriyanti. (2017).

"Analisis Pengaruh Likuiditas Profitabilitas Leverage Terhadap Kebijakan Dividen ( Studi Pada Perusahaan Manufaktur Yang Terdaftar Di Bursa Efek Indonesia Periode Tahun 2013 - 2017 )." Sustainable Competitive Advantage-9 (Sca-9) Feb Unsoed 9(1): 1-22.

Cahyadi, Rino Tam, Lilik Purwanti, and Endang Mardiati. (2016). "Pengaruh Profitabilitas, Dewan Komisaris, Komisaris Independen Dan Risiko Idiosinkratis Terhadap Dividen Payout Ratio." Jurnal Economia 14: 99-112.

Chandrarin, Grahita. (2017). Metode 
Riset Akuntansi Pendekatan Kuantitatif. Jakarta: Salemba Empat.

Elmagrhi, Mohamed H., Collins G. Ntim, Richard M. Crossley, John Kalimilo Malagila, et al. (2017). "Corporate Governance and Dividend Pay-out Policy in UK Listed SMEs: The Effect of Corporate Board Characteristics." International Journal of Accounting \& Information Management.

Finingsih, Okta, Siti Nurlaela, and Kartika Hendra Titisari. (2018). "Profitabilitas, Likuiditas, Leverage Dan Pertumbuhan Perusahaan Terhadap Kebijakan Dividen Pada Perusahaan Pertanian Di Bursa Efek Indonesia." Jurnal Ekonomi Paradigma 20(02): 44-51.

Firdaus, Iwan, and Gean Karlos Purba. (2019). "Pengaruh Kinerja Keuangan Perusahaan Terhadap Devidend Payout Ratio." Jurnal Ekonomi XXIV(01): 31-45.

Ghozali, Imam. (2018). Aplikasi Analisis Multivariate: Dengan Program IBM SPSS 25 Edisi 9. Semarang: Universitas Diponegoro.

Gumanti, Tatang Ary. (2013). Kebijakan Dividen: Teori, Empiris Dan Implikasi. Yogyakarta: UPP STIM YKPN.

Hery. (2013). Rahasia Pembagian Dividen \& Tata Kelola Perusahaan. Yogyakarta: Gava Media.

Jayanti, Ida Setya Dwi, and Ayu

Febriyanti Puspitasari. (2017).

"Struktur Kepemilikan Dan

Kebijakan Dividen Pada

Perusahaan Manufaktur Di Indonesia." The Indonesian Journal of Applied Business 1(1): 1-13.

Jensen, Michael $\mathrm{C}$, and William $\mathrm{H}$ Meckling. (1976). "Theory of the Firm: Managerial Behavior, Agency Costs and Ownership Structure." Journal of Financial
Economics 3(4): 305-60.

Minovia, Arie Frianola, Yunilma, and Rudi Dharma Putra. (2013). "Pengaruh Proporsi Dewan Komisaris Independen, Jumlah Rapat Dewan Komisaris Dan Jumlah Rapat Komite Audit Terhadap Corporate Environental Disclosure." Universitas Bung Hatta.

Permanasari, Meiryananda. (2017). "Faktor - Faktor Yang Mempengaruhi Kebijakan Dividen Pada Perusahaan Mom Keuangan Di Indonesia." Jurnal Bisnis dan Akuntansi 19(1): 27-37.

Permataningrum, Yasodhara Intan, and Steven Yap. (2017). "Faktor Faktor Yang Mempengaruhi Dividen Policy Pada Perusahaan Makanan, Minuman Dan Tembakau Yang Terdaftar Di Bursa Efek Indonesia." JURNAL BISNIS DAN AKUNTANSI 19(1): 237-42.

Priyatno, Duwi. (2013). Analisis Korelasi, Regresi Dan Multivariate Dengan SPSS. Yogyakarta: Gava Media.

Sani, Alhaji, and Awaisu Muhammad Musa. (2017). "Corporate Board Attributes and Dividend Payout Policy of Listed Deposit Money Banks in Nigeria." International Journal of Research in IT, Management and Engineering 07(1): 7-13.

Setiawan, Yudi, and Etna Nur Afri Yuyetta. (2013). "Pengaruh Independensi Dewan Komisaris, Reputasi Auditor, Rasio Hutang Dan Collateralizable Assets Terhadap Kebijakan Dividen (Studi Empiris Pada Perusahaann Manufaktur Yang Terdaftar Di Bursa Efek Indonesia Periode 2009-2011)." Diponegoro Journal Of Accounting Vol. 3(No. 1): 1-11. 
JASa (Jurnal Akuntansi, Audit dan Sistem Informasi Akuntansi)

Vol. 4 No. 3/ December 2020

ISSN 2550-0732 print / ISSN 2655-8319 online

Setiyowati, Supami Wahyu, and Ati

Retna Sari. (2017). "Pengaruh

Corporate Governance Dan Kinerja

Keuangan Terhadap Kebijakan

Deviden Pada Perusahaan

Manufaktur Yang Listing Di Bursa

Efek Indonesia Tahun 2014 -2015."

Jurnal AKSI (Akuntansi dan Sistem

Informasi) 1: 45-57.

Shahid, Muhammad Sadiq, Faid Gul,

Muhammad Rizwan, and

Muhammad Hassan Bucha. (2016). "Ownership Structure , Board Size , Board Composition and Dividend Policy: New Evidence from Two Emerging Markets Ownership Structure, Board Size , Board Composition And Dividend Policy: New Evidence from Two Emerging Markets." Journal of Business Studies-JBS 12(2): 25-36. 